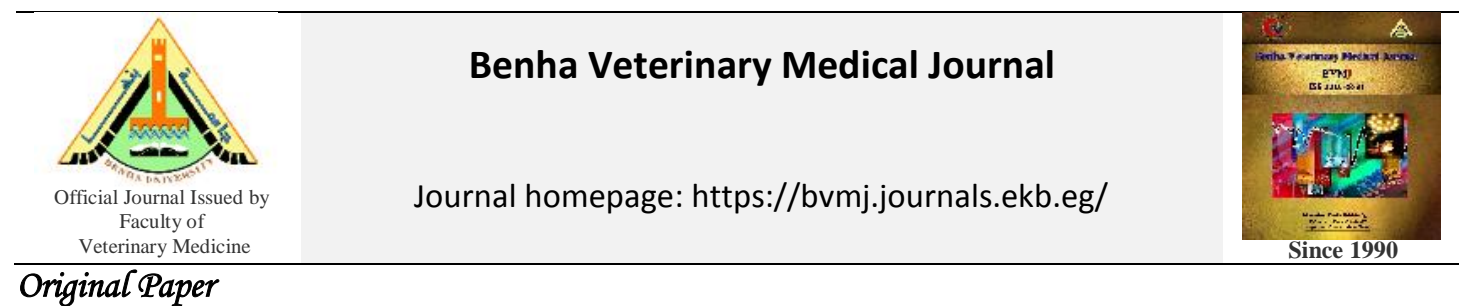

\title{
Control of some septicemic bacterial infections in Oreochromis niloticus, with special reference to their antimicrobial resistant genes
}

Hadeer Youssuf, Amel M. El Asely*, Eman A. Abdel Gawad, Amany A. Abbass, Adel A. Shaheen*

Department of Aquatic Animals Diseases and Management, Faculty of Veterinary Medicine, Benha University, Egypt.

\begin{tabular}{|c|c|}
\hline ARTICLE INFO & ABSTRACT \\
\hline $\begin{array}{l}\text { Keywords } \\
\text { Antibiogram profile } \\
\text { Antimicrobial resistant } \\
\text { gens } \\
\text { Bacterial diseases } \\
\text { Nile tilapia }\end{array}$ & $\begin{array}{l}\text { The current study aimed to control the bacterial infection associated with summer mortalities } \\
\text { in Nile tilapia. The sensitivity of the isolated bacteria, including Aeromonas Veronii (A. } \\
\text { veronii) strain (HY1, HY2, HY3, HY4 and HY6), Citrobacter freundii ( } C \text {. freundii), Proteus } \\
\text { vulgaris ( } P \text {. vulgaris) and pseudomonas flurosence ( } P \text {. flurosence) for antibiotic was tested and } \\
\text { antibiotic resistant genes were investigated. In order to verify the result of antibiotic sensitivity; } \\
\text { experimental trial was performed to determine the effect of florfenicol and erythromycin } \\
\text { against Nile tilapia (Oreochromis niloticus) infection with different pathogenic bacteria [ } 4 \\
\text { strains of } A \text {. veronii (AHY2), AHY3), AHY4) and AHY6), C. freundii, P. flurosence and } P \text {. } \\
\text { vulgaris]. The results revealed that all tested bacterial isolates were } 100 \% \text { sensitive to } \\
\text { florfenicol and erythromycin, } 50 \% \text { sensitive to gentamycin, } 25 \% \text { sensitive to nalidixic acid } \\
\text { and sulphamethoxazol-trimethoprim, while all bacterial isolates were } 100 \% \text { resistant to } \\
\text { oxytetracycline and tetracycline lincomycin, ofloxacillin and penicillin, } 87.5 \% \text { resistant to } \\
\text { ampicillin, } 75 \% \text { resistant to sulphamethoxazol-trimethoprim, } 62.5 \% \text { for nalidixic acid and } \\
37.5 \% \text { for gentamycin. The relative percent survival (RPS) of challenged medicated fish with } \\
\text { erythromycin ranged from } 45.0-91.7 \% \text {. Where, the survival } \% \text { in } H Y 3 \text { infected groups was the } \\
\text { highest }(91.7 \% \text { ) followed by C. freundii ( } 87.5 \%), H Y 6 \text { ( } 83.3 \% \text { ) and P. vulgaris }(81.3 \% \text { ). }\end{array}$ \\
\hline
\end{tabular}

\section{INTRODUCTION}

Tilapia culture is steeping toward the top in the field of aquaculture industry, where the world tilapia aquaculture production is grown $12 \%$ per year (FAO, 2017). Tilapia fish farms are vulnerable to various bacterial infections which necessitate the usage of antimicrobials. However, with the expansion of fish farms and intensification systems, the overuse of antimicrobials leads to emerging of new bacterial strains which acquired resistance to the antimicrobial agents (Watts et al., 2017). Most of antimicrobial resistance (AMR) occurs through mutation, horizontal gene transfer (HGT), or through natural transformation, transduction, or conjugation (von Wintersdorff et al., 2017). The incidence of antimicrobial resistance in fish shows the chance of transfer of AMR genes to humans, and the difficulty in controlling diseases (Santos and Ramos, 2018), which lead to their limitation and developing laws and legislations for antimicrobial use in aquaculture (Okocha et al., 2018).

In order to reduce AMR, a necessary attempt to determine the bacterial sensitivity to the approved antimicrobials should be adopted (AVMA 2006). Limitation are facing the farmers for choosing the antimicrobial agent, hence; only three antimicrobials; oxytetracycline (Terramycin ${ }^{\circledR} 200$ ), florfenicol (Aquaflor $\AA$ ) and ormethoprim and sulfadimethoxine (Romet30) are approved by the United States Food and Drug Administration (USFDA) as feed additives in aquaculture sector ( Manyi-Loh et al., 2018) Florfenicol has been used as medicated feed for controlling Vibrio anguillarum,
Aeromonas salmonicida, Streptococcus iniae, Listonella anguillarum, and Edwardsiella ictaluri in different fish species (Darwish, 2007., Gaunt et al., 2003., Samuelsen et al., 1998., Samuelsen and Bergh, 2004., Seljestokken et al., 2006). Although erythromycin is not found in the approved antimicrobials list, but it is proved effective in treatment Flavobacterium psychrophilum (Jarau et al., 2019), and it was used as a prophylactic against bacterial kidney disease (Elliot, 2017).

The aim of this work was to control the bacterial infection based on the data obtained from the antimicrobial profile and the AMR genes

\section{MATERIAL AND METHODS}

\subsection{Bacterial isolates}

In the present study; A. veronii (HY1, HY2, HY3, HY4 and HY6), C. freundii, P. vulgaris and P. flurosence isolated from diseased Nile tilapia during summer mass mortality were used. All the isolates were previously identified on phenotypic and molecular basis (Youssuf et al., 2020).

\subsection{Antimicrobial sensitivity test and antimicrobial} resistance index (AMR)

The selected bacterial strains were grown overnight in Muller Hinton broth (MHB) (Oxoid, UK) at $28^{\circ} \mathrm{C}$ for $24 \mathrm{hr}$. Then the bacterial suspension was inoculated on Muller Hinton Agar (MHA) (Oxoid, UK) plates and the discs of 11 chemotherapeutic agents (Oxoid, UK) were placed firmly on the surface of the agar. The plates were incubated at $28^{\circ} \mathrm{C}$

* Corresponding author: amlvet@yahoo.com; shaheen_aa@yahoo.com 
for $24 \mathrm{~h}$. The results were determined by measuring the diameter of the inhibition zones and the interpretation of inhibition zones were carried out using NCCLS (2000) guidelines (Table 1). The multiple antimicrobial resistant (MAR) index was calculated according to Schwarz et al., (2010) by dividing the total number of resistance to antimicrobials by each isolate on the total numbers of tested antimicrobials.

\subsection{Determination of antimicrobial resistant genes of the pathogenic bacteria}

Based on the antibiogram result, a total of seven pathogenic strains including four strains of A. veronii (AHY2), AHY3), $A H Y 4)$ and $A H Y 6)$ ), $C$. freundii, $P$. flurosence and $P$. vulgaris were selected for determination of antimicrobial resistant genes. DNA extraction was performed from strains resistant to more than one antibiotic, using QIAamp DNA mini kit according to the manufacturer instructions. Identification of different antimicrobial resistant genes coding was performed using PCR amplification with specific forward and reverse oligonucleotide primers listed in table (2). PCR reactions were carried out in 251 volumes containing $6 l$ of DNA, $1 \quad l$ of each primer (20 pmol), and 12.5 lof Emerald Amp GT PCR Master Mix (2x premix) and $4.5 l$ of PCR grade water. All PCR reactions were done at $94^{\circ} \mathrm{C}$ for $5 \mathrm{~min}, 35$ cycles at $94^{\circ} \mathrm{C}$ for $30 \mathrm{~s}, 60^{\circ} \mathrm{C}$ for $1 \mathrm{~min}$, $72^{\circ} \mathrm{C}$ for $1 \mathrm{~min}$, followed by a final elongation at $72{ }^{\circ} \mathrm{C}$ for $10 \mathrm{~min}$. The obtained PCR products were analyzed by electrophoresis.

\subsection{Using chemotherapy for controlling of pathogenic} bacterial infection in Nile tilapia

2.4.1. Preparation of medicated diet
Florfenicol (Floribiotic $100 \%$, ATCO Pharma) medicated diet was prepared at concentration of $15 \mathrm{mg} / \mathrm{kg}$ fish following Soto et al., (2010), while, erythromycin (Ucimycin P.F, 20\%, Muveco, veterinary pharmaceuticals, fodder concentrates company) medicated diet was carried out at a concentration of $50 \mathrm{mg} / \mathrm{kg}$ fish body weight according to Phuoc et al. (2010). The required dose of the chemotherapy was dissolved in an appropriate amount of tap water and mixed with $1000 \mathrm{~g}$ crushed commercial diet to produce dough. The diet was re-pelleted using hand pelletizer, dried at room temperature for $48 \mathrm{hr}$. The medicated diets were packaged and stored at $4{ }^{\circ} \mathrm{C}$.

\subsubsection{Experimental Design}

About 440 Nile tilapia fingerlings $(20 \pm 5 \mathrm{~g}$ average body weight) were transported alive from fish farm at Kafr ElSheikh to the wet laboratory of Aquatic Animal Diseases and Management, Faculty of Veterinary Medicine, Moshtohor, Benha University. Fish were kept in well prepared fiber glass tanks ( $750 \mathrm{~L}$ capacity) for 2 weeks to be acclimated for laboratory conditions. Each tank was supplied with an air pump and dechlorinated tap water. Then fish were maintained at stocking densities of 10 fish per glass aquaria $(100 \times 100 \times 50)$, the water parameters were adjusted as following; water temperature $27 \pm 2{ }^{\circ} \mathrm{C}$, dissolved oxygen $6 \pm 0.5 \mathrm{mg} / \mathrm{L}$, total ammonia concentration $0.53 \pm 0.07 \mathrm{mg} / \mathrm{L}$ and $\mathrm{pH} 7 \pm 0.2$. Fish were fed with $4 \%$ body weight basal diet (30\% protein) twice daily (Mesko, 1985). After two weeks acclimation, fish were randomly distributed into 22 group in duplicate (10 fish/replicate) in well prepared glass aquaria supplied with aeration and de-chlorinated tap water. The health status of fish was determined during acclimation period according to Austin and Austin (2007).

Table 1 The different antimicrobial discs used in sensitivity test with interpretation of the inhibitory zone

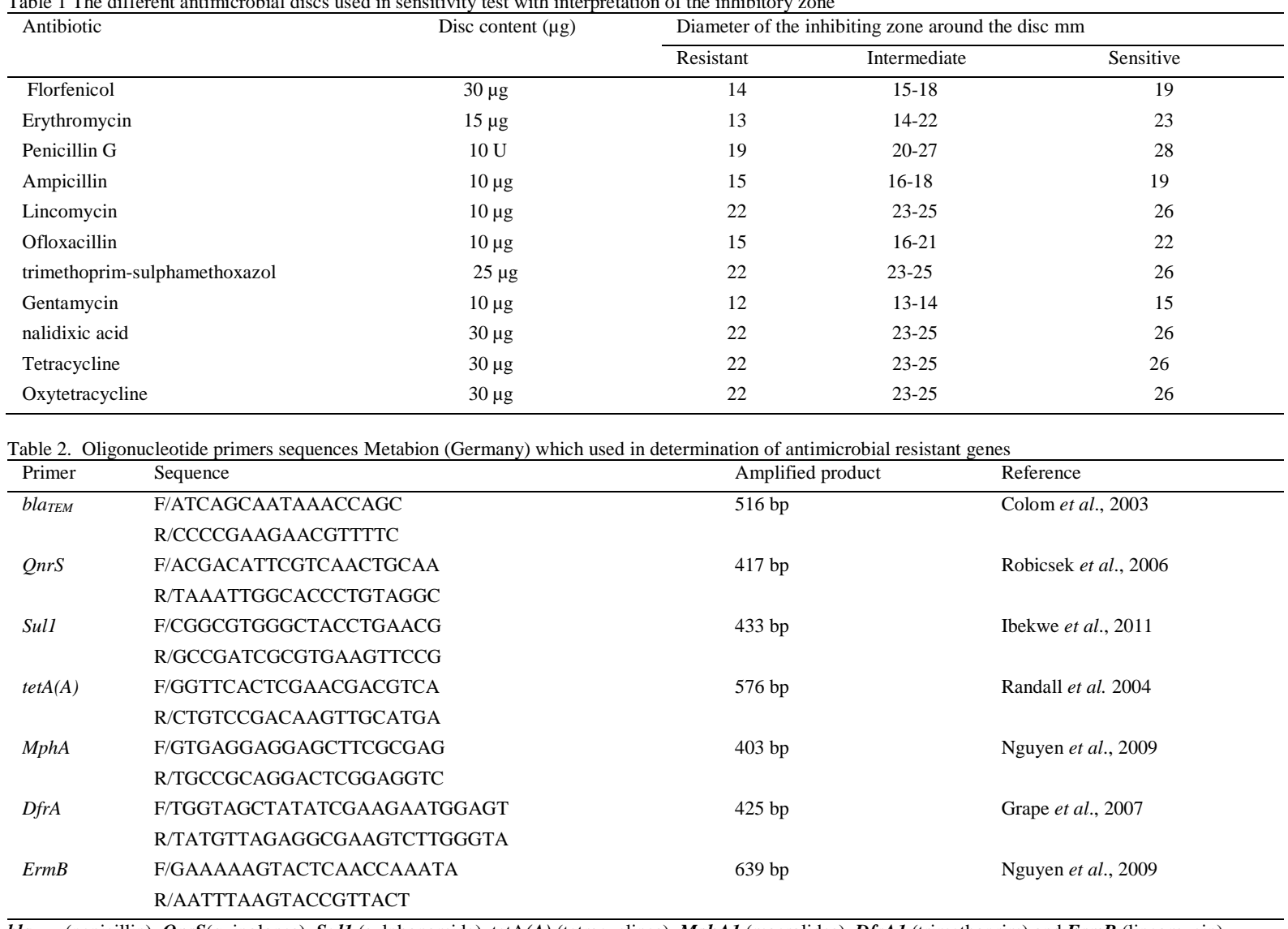

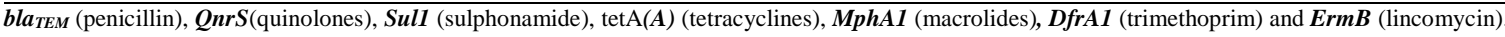


Fish were divided into three main groups, main group1; MG1; (with 7 subgroups) in which fish were fed florfenicol medicated diet and fish in each subgroup was (IP) challenged with $0.2 \mathrm{ml}$ of the identified pathogenic bacteria (4 strains of A. veronii (AHY2), A (HY3), A(HY4) and $A(H Y 6))$, C. freundii, $P$. flurosence and $p$. vulgaris) to achieve $1.8 \times 10^{8}$ cells/fish. Main group2; MG2; (with 7 subgroups) in which fish were fed erythromycin medicated diet and fish in each subgroup was (IP) challenged with 0.2 $\mathrm{ml}$ of the same identified pathogenic bacteria (4 strains of $A$. veronii [(AHY2), AHY3), AHY4) and AHY6)], C. freundii, $P$. flurosence and $p$. vulgaris) to achieve $1.8 \times 10^{8}$ cells/fish. Main group3; MG3; (with 7 subgroups) in which fish were fed basal diet and (IP) challenged with $0.2 \mathrm{ml}$ of the pathogenic bacteria [4 strains of A. veronii (AHY2), AHY3), $A H Y 4$ ) and AHY6)], C. freundii, P. flurosence and $p$. vulgaris) to achieve $1.8 \times 10^{8}$ cells/fish, these groups were considered as control positive groups. Control negative (non-infected group) was fed basal diet. The treatment in all groups was started just after appearance of septicemic signs. Fish in experimentally treated and control groups was fed at $4 \%$ of their body weight twice a day along the experimental period (10 days). Clinical signs, post-mortem lesions and mortalities were recorded during the experiment. The protocol of work was approved with a number (BUFVTM-
06-07-20), and monitored by the Ethics Committee of the Faculty of Veterinary Medicine, Benha University, Egypt.

\section{RESULTS}

The antibiogram profile revealed that the (AHY2) strain showed resistance to ampicillin, lincomycin, tetracycline, ofloxacillin, oxytetracycline and penicillin. (AHY3) strain and $C$. freundii showed resistance to ampicillin, lincomycin, nalidixic acid, tetracycline, ofloxacillin, oxytetracycline, penicillin and sulphamethoxazol- trimethoprim. (AHY4) and $P$. flurosence showed resistance to ampicillin, lincomycin, nalidixic acid, tetracycline, ofloxacillin, oxytetracycline, penicillin, sulphamethoxazol- trimethoprim and gentamycin. (AHY6) strain) showed resistance to lincomycin, nalidixic acid, tetracycline, ofloxacillin, oxytetracycline, penicillin, Sulphamethoxazoltrimethoprim and gentamycin and $(P$. vulgaris) showed resistance to ampicillin, lincomycin, tetracycline, ofloxacillin, oxytetracycline, penicillin and sulphamethoxazol- trimethoprim, Also strain $(A H Y l)$ showed moderate resistance to the six chemotherapeutic agents (ampicillin, lincomycin, tetracycline, ofloxacillin, oxytetracycline and penicillin) at rate of $54.5 \%$ (Table 3 ).

Table (3): Degree of sensitivity of bacterial isolates to every antimicrobial agent.

\begin{tabular}{|c|c|c|c|c|c|c|c|c|c|c|c|}
\hline \multirow{2}{*}{$\begin{array}{l}\text { Bacterial } \\
\text { Isolates }\end{array}$} & \multicolumn{11}{|c|}{ Antimicrobial agents } \\
\hline & $\begin{array}{l}\text { ampicillin } \\
\text { (Amp) } \\
10 \mathrm{~g}\end{array}$ & $\begin{array}{l}\text { gentamycin } \\
\text { (GN) } \\
10 \mathrm{~g}\end{array}$ & $\begin{array}{l}\text { lincomycin } \\
\text { (MY) } \\
10 \mathrm{~g}\end{array}$ & $\begin{array}{l}\text { nalidixic } \\
\text { acid } \\
\text { (NA) } \\
30 \mathrm{~g} \\
\end{array}$ & $\begin{array}{l}\text { tetracycline } \\
\text { (TE) } \\
30 \mathrm{~g}\end{array}$ & $\begin{array}{l}\text { ofloxacillin } \\
\text { (OFX) } \\
10 \mathrm{~g}\end{array}$ & $\begin{array}{l}\text { oxytetracycline } \\
\text { (OT) } \\
30 \mathrm{~g}\end{array}$ & $\begin{array}{l}\text { sulphamethoxazol- } \\
\text { trimethoprim } \\
\text { (SXT) } \\
25 \mathrm{~g} \\
\end{array}$ & $\begin{array}{l}\text { Penicillin G } \\
10 \mathrm{U}\end{array}$ & $\begin{array}{l}\text { Erythromycin } \\
15 \mathrm{~g}\end{array}$ & $\begin{array}{l}\text { Florfenicol } \\
30 \mathrm{~g}\end{array}$ \\
\hline $\begin{array}{l}\text { A. veronii } \\
\text { (HY1) }\end{array}$ & $\mathrm{R}$ & $\mathrm{S}$ & $\mathrm{R}$ & S & $\mathrm{R}$ & $\mathrm{R}$ & $\mathrm{R}$ & $\mathrm{S}$ & $\mathrm{R}$ & $\mathrm{S}$ & $\mathrm{S}$ \\
\hline $\begin{array}{l}\text { A. veronii } \\
\text { (HY2) }\end{array}$ & $\mathrm{R}$ & $\mathrm{S}$ & $\mathrm{R}$ & $S$ & $\mathrm{R}$ & $\mathrm{R}$ & $\mathrm{R}$ & S & $\mathrm{R}$ & $S$ & $\mathrm{~S}$ \\
\hline $\begin{array}{l}\text { A veronii } \\
\text { (HY3) }\end{array}$ & $\mathrm{R}$ & S & $\mathrm{R}$ & $\mathrm{R}$ & $\mathrm{R}$ & $\mathrm{R}$ & $\mathrm{R}$ & $\mathrm{R}$ & $\mathrm{R}$ & S & $\mathrm{S}$ \\
\hline $\begin{array}{l}\text { A. veronii } \\
\text { (HY4) }\end{array}$ & $\mathrm{R}$ & $\mathrm{R}$ & $\mathrm{R}$ & $\mathrm{R}$ & $\mathrm{R}$ & $\mathrm{R}$ & $\mathrm{R}$ & $\mathrm{R}$ & $\mathrm{R}$ & S & S \\
\hline $\begin{array}{l}\text { A. veronii } \\
\text { (HY6) }\end{array}$ & I & $\mathrm{R}$ & $\mathrm{R}$ & $\mathrm{R}$ & $\mathrm{R}$ & $\mathrm{R}$ & $\mathrm{R}$ & $\mathrm{R}$ & $\mathrm{R}$ & S & $\mathrm{S}$ \\
\hline \multirow{2}{*}{$\begin{array}{l}\text { Proteus } \\
\text { vulgaris } \\
\text { Pseudomonas } \\
\text { Flurosence }\end{array}$} & $\mathrm{R}$ & I & $\mathrm{R}$ & I & $\mathrm{R}$ & $\mathrm{R}$ & $\mathrm{R}$ & $\mathrm{R}$ & $\mathrm{R}$ & S & $\mathrm{S}$ \\
\hline & $\mathrm{R}$ & $\mathrm{R}$ & $\mathrm{R}$ & $\mathrm{R}$ & $\mathrm{R}$ & $\mathrm{R}$ & $\mathrm{R}$ & $\mathrm{R}$ & $\mathrm{R}$ & S & S \\
\hline $\begin{array}{l}\text { Citrobacter } \\
\text { freundii }\end{array}$ & $\mathrm{R}$ & $\mathrm{S}$ & $\mathrm{R}$ & $\mathrm{R}$ & $\mathrm{R}$ & $\mathrm{R}$ & $\mathrm{R}$ & $\mathrm{R}$ & $\mathrm{R}$ & S & $\mathrm{S}$ \\
\hline & \multicolumn{11}{|c|}{ Degree of sensitivity of bacterial isolates to every antimicrobial agent } \\
\hline $\begin{array}{l}\% \text { of } \\
R\end{array}$ & 87.5 & 37.5 & 100 & 62.5 & 100 & 100 & 100 & 75 & 100 & 0 & 0 \\
\hline $\begin{array}{l}\% \text { of } \\
\text { I }\end{array}$ & 12.5 & 12.5 & 0 & 12.5 & 0 & 0 & 0 & 0 & 0 & 0 & 0 \\
\hline $\begin{array}{l}\% \text { of } \\
\text { S }\end{array}$ & 0 & 50 & 0 & 25 & 0 & 0 & 0 & 25 & 0 & 100 & 100 \\
\hline
\end{tabular}

S: Sensitive. R: Resistant. I: Intermediate. \%= No. of R or I or S bacteria $\times 100$ Total No. of bacteria

Data of the multiple antimicrobial resistances (MAR) index are present in Table 4. Data showed that the multidrug resistance pattern of the bacterial isolates and MAR index values ranged between 0.54 and 0.81 .

All tested bacterial isolates [A. veronii (HY1, HY2, HY3, HY4 and $H Y 6), C$. freundii, $P$. vulgaris and $P$. flurosence $]$ were $100 \%$ sensitive to florfenicol and erythromycin, $50 \%$ sensitive to gentamycin, $25 \%$ sensitive to nalidixic acid and sulphamethoxazol-trimethoprim, while sensitivity to other antibiotic discs was $0 \%$. In addition, all bacterial isolates were $100 \%$ resistant to oxytetracycline and tetracycline lincomycin, ofloxacillin and penicillin, $87.5 \%$ resistant to ampicillin, $75 \%$ resistant to sulphamethoxazoltrimethoprim, $62.5 \%$ for nalidixic acid and $37.5 \%$ for gentamycin (Table 4).
Table 4. Percentages of antimicrobial resistance to the different antimicrobials used in the antimicrobial sensitivity test

\begin{tabular}{lcc}
\multicolumn{3}{c}{ microbials used in the antimicrobial sensitivity test } \\
\hline Aeromonas spp. Isolates & $\begin{array}{c}\text { Antimicrobial profile } \\
\text { No. of R. agents }\end{array}$ & MAR Index \\
\hline$A(H Y 1)$ & 6 & 0.54 \\
$A(H Y 2)$ & 6 & 0.54 \\
$A(H Y 3)$ & 8 & 0.72 \\
$A(H Y 4)$ & 9 & 0.81 \\
$A(H Y 6)$ & 8 & 0.72 \\
Proteus vulgaris & 8 & 0.72 \\
P. flurosence & 9 & 0.81 \\
Citrobacter freundii & 8 & 0.72 \\
\hline
\end{tabular}

The antimicrobial resistant genes of [(A HY2), A HY3), A HY4), A HY6)], $P$. vulgaris, $P$. fluorescence and $C$. freundii) were tested. These isolates were found to be associated with all virulent genes (Ermb (lincomycin), Tem (penicillin), Teta 
(tetracyclines), Sul1 (sulphonamide), Dfra (trimethoprim), Mpha (macrolides) and Qnr (quinolones) related to these antibiotics (Fig. 1 and Fig. 2).

Moreover, they were resistant to frequently used antibiotics for human infections. The bacterial strains revealed resistance to penicillin at $516 \mathrm{bp}$, Trimethoprim at $425 \mathrm{bp}$, macrolides at $403 \mathrm{bp}$, quinolones at $417 \mathrm{bp}$, tetracycline at $576 \mathrm{bp}$, lincomycin at $639 \mathrm{bp}$ and sulphonamide at $433 \mathrm{bp}$. The treatment trial indicated that the Relative percent survival (RPS) of challenged medicated fish with florfenicol ranged from $44-100 \%$ within ten days post-infection, being the highest (100\%), especially with Aeromonas strains $H Y 3$ $(83.3 \%)$ and HY6 . However, $100 \%$ survivability was evident for Proteus vulgaris, $C$. freundii and P. flurosence (Table 5).

Relative percent survival (RPS) of challenged medicated fish with erythromycin ranged from $39-91.7 \%$ in A. veronii strains, where the highest survival of 83.3 and $91.7 \%$ was evident in $H Y 6$ and $H Y 3$; respectively. Similarly, higher survivability was noticed in C. freundii (87.5\%), HY6 (83.3 $\%)$ and P. vulgaris $(81.3 \%$ ) (Table 6$)$. The challengedmedicated fish showed no abnormal signs and appeared healthy. The challenged control group survival rate was $0 \%$ with aeromonase strain (A HY2), $10 \%$ for (A HY4), $40 \%$ for A HY3, AHY6), 20\% for (P. vulgaris and $C$. freundii) and $60 \%$ for $P$. flurosence. Meanwhile, Aeromonas strains (HY2 and $H Y 4$ ) reached $50 \%$ mortality.

\section{DISUCSSION}

Bacterial diseases are one of the many challenges facing aquaculture development (Aly, 2013). Among others, motile Aeromonas septicemia (MAS), caused by Aeromonas spp., is one of the important bacterial infections, leading to mass mortalities in fish and severe economic losses (Noga, 2010, Assefa and Abunna, 2018). Antibiotic usage in fish farms is widespread either for the prevention or treatment of bacterial infections in fish (Cabello et al., 2013), however; their misuse has led to the emergence of bacterial species with multiple drug resistance all over the world. Our data revealed that most of bacterial isolates showed high resistance rates to several antimicrobials, since strains showed resistance to at least 6 out of 11 evaluated antibiotics.

Table 5. Efficacy of florfenicol in the treatment of experimentally O.niloticus challenged with the pathogenic bacterial isolates.

\begin{tabular}{|c|c|c|c|c|}
\hline Bacterial isolates & $\begin{array}{l}\text { (Control - ve) } \\
\% \text { of dead fish }\end{array}$ & $\begin{array}{l}\text { (Control + ve) } \\
\% \text { of dead fish }\end{array}$ & $\begin{array}{c}\text { (Treated group) } \\
\% \text { of dead fish }\end{array}$ & Relative percent survival (RPS) of treated group \\
\hline$A(H Y 2)$ & $0 \%$ & $100 \%$ & $50 \%$ & 50 \\
\hline$A(H Y 3)$ & $0 \%$ & $60 \%$ & $0 \%$ & 100 \\
\hline$A(H Y 4)$ & $0 \%$ & $90 \%$ & $50 \%$ & 44.4 \\
\hline$A(H Y 6)$ & $0 \%$ & $60 \%$ & $10 \%$ & 83.3 \\
\hline Proteus vulgaris & $0 \%$ & $80 \%$ & $0 \%$ & 100 \\
\hline P. flourosence & $0 \%$ & $40 \%$ & $0 \%$ & 100 \\
\hline C.freundii & $0 \%$ & $80 \%$ & $0 \%$ & 100 \\
\hline
\end{tabular}

Table 6. Efficacy of erythromycin in the treatment of experimentally O.niloticus challenged with the pathogenic bacterial isolates.

\begin{tabular}{|c|c|c|c|c|}
\hline Bacterial isolates & $\begin{array}{l}\text { (Control - ve) } \\
\% \text { of dead fish }\end{array}$ & $\begin{array}{l}\text { (Control }+ \text { ve }) \\
\% \text { of dead fish }\end{array}$ & $\begin{array}{l}\text { (Treated group) } \\
\% \text { of dead fish }\end{array}$ & Relative percent survival (RPS) of treated group \\
\hline$A(H Y 2)$ & $0 \%$ & $100 \%$ & $55 \%$ & 45 \\
\hline$A(H Y 3)$ & $0 \%$ & $60 \%$ & $5 \%$ & 91.7 \\
\hline$A(H Y 4)$ & $0 \%$ & $90 \%$ & $55 \%$ & 38.9 \\
\hline$A(H Y 6)$ & $0 \%$ & $60 \%$ & $10 \%$ & 83.3 \\
\hline Proteus vulgaris & $0 \%$ & $80 \%$ & $15 \%$ & 81.3 \\
\hline P. flourosence & $0 \%$ & $40 \%$ & $20 \%$ & 50 \\
\hline C. freundii & $0 \%$ & $80 \%$ & $10 \%$ & 87.5 \\
\hline
\end{tabular}



A(HY6), Proteus vulgaris, Pseudomonas flourosence and Citrobacter freundii) positive. Neg=Negative control, pos=Positive control, L=Marker

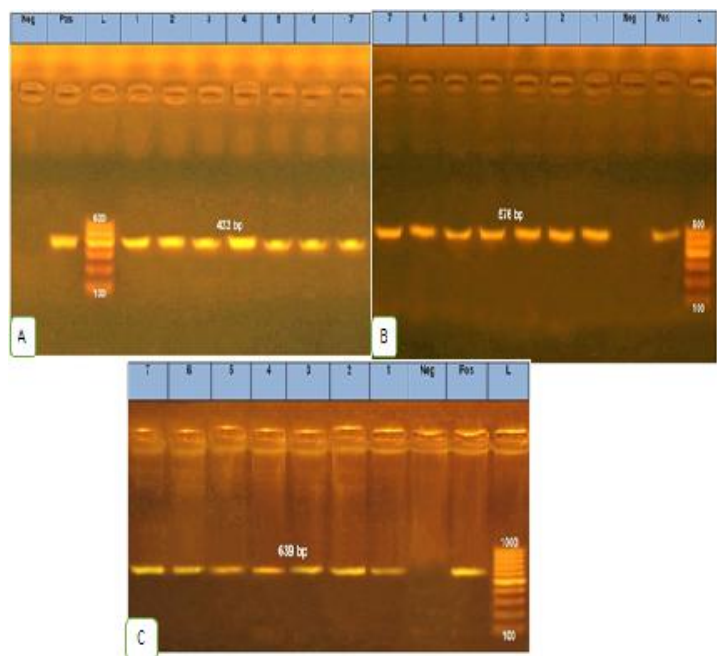

Fig. 2 PCR amplification of A): sul1gene related to (sulphonamide) at 433. B) tetA gene related to (tetracyclin) at 576. C): ermB gene related to (lincomycin) at $639 \mathrm{bp}$. Lane: 1 
7 (A(HY2), A(HY3), A(HY4), A(HY6), Proteus vulgaris, Pseudomonas flourosence and Citrobacter freundii) positive. Neg=Negative control, pos=Positive control, L=Marker.

All bacterial isolates were $100 \%$ resistant to oxytetracycline, tetracycline, lincomycin, ofloxacillin and penicillin. This result was consistent with previous studies (Rhodes et al. (2000), Kim et al. (2004) and Hatha et al. (2005)). The modest extent of resistance in our study is surprising as tetracyclines are widely used for control of most bacterial fish diseases in aquaculture in Egypt. A considerable overall increase in drug resistance of fish pathogenic bacteria is parallel with the extensive use of chemotherapeutic agents, which has created a great difficulty in the treatment of bacterial infections in fish (Aoki et al., 1992). It was found that all tested bacterial isolates were highly sensitive to florfenicol (100\%). Similarly, Abdel-Latif and Sedeek, (2017) found that isolated strains about (144 Enterobacteriaceae strains) which were derived from diseased fish and were markedly sensitive to gentamycin, florfenicol, and flumequine, moderately sensitive to doxycycline and less sensitive to oxytetracycline, erythromycin, and ampicillin. But the difference in sensitivity to erythromycin in our study may be due to difference in bacterial isolates and extensive use and misuse of these antibiotics. Our results showed resistance to more than one class of antibiotic (Multiple drug resistance) which has been reported for fish pathogens in several studies (Schmidt et al., 2000 and Hatha et al., 2005). The high resistance levels of bacteria to antimicrobials, which due to the frequent use of antibiotics either as growth promoters or therapeutic agents for various diseases. MAR index of our isolates showed high ranges between 0.54 and 0.81 . In the same context, MAR index ranged between 0.27 and 0.82 in the study of El Gohary et al., (2020).

A variety of resistance patterns was observed in our study which explained by determination of antimicrobial resistant genes as the isolates (AHY2), AHY3), AHY4), AHY6), $P$. vulgaris, $P$. fluorescence and $C$. freundii were found to be associated with all virulence genes detected; Ermb (lincomycin), Tem (penicillin), Teta (tetracyclines), Sul1(sulphonamide), Dfra (trimethoprim), Mpha (macrolides) and Qnr (quinolones). The spread of tet genes is often facilitated by their location on mobile genetic elements, such as plasmids and transposons (Chopra and Roberts, 2001). Plasmid-mediated quinolone resistance in bacteria associated with fish farms has been detected in several countries. The identification of QnrS determinants in Aeromonas spp. suggests that they may act as an environmental reservoir of qnrS genes, as already described for tet genes (Rhodes et al., 2000 and Schmidt et al., 2001). Some of our bacterial isolates confirmed to have resistant genes to some antibiotics, whereas invitro they proved to be sensitive to those antibiotics, as (A(HY2) was sensitive to sulphamethoxazol-trimethoprim, while $\mathrm{A}(\mathrm{HY} 4)$ and $\mathrm{A}(\mathrm{HY} 2)$ were sensitive to lincomycin. Our explanation is those strains may have nonfunctional genes which doesn't work and this came in accordance to Zheng et al., (2007) who reported that Pseudogenes are DNA fragments, related to recognized genes, which have lost their protein-coding ability or are no longer expressed in the cell. Pseudogenes originate from retro transposition or genomic duplication of functional genes and become "genomic fossils" that are nonfunctional attributed to mutations that inhibit gene transcription, such as in the region of the promoter of genes, or fatally alter the translation of the gene, such as premature stop codons or frameshifts. Pseudogenes resulting from the retro transposition of an RNA intermediate are known as processed pseudogenes; pseudogenes that arise from the genomic remains of duplicated genes or residues of inactivated genes are non-processed pseudogenes (Zheng et al., 2007). Additionally, David et al., (2009) about his work on E. coli, stated that although a wide variety of expression hosts would need to be employed, for the detection of cloned functional resistance from different bacterial genera. The transformation of the transmitted genes into functional genes in new hosts would require comprehensive mutation and recombination "tailoring." Native proponents need to be changed to allow transcription and translation in the new hosts.

The use of feed treatments is the most convenient method on the large scale aquaculture, to avoid the stress and reduce labor (Robb and Crampton, 2013), but it is important to start feeding before fish stop eating (i.e; tend to be sick); otherwise the benefit of the delivered medication wouldn't be achieved.

The experimental trial indicated that survivability of challenged medicated fish with florfenicol was nearly at the same erythromycin treated fish, compared to the infected non-treated groups, which indicate the effectiveness in controlling the infection. Similarly, Darwish, (2007) reported that the daily florfenicol dose of $15 \mathrm{mg} / \mathrm{kg} \mathrm{BW}$ for $10 \mathrm{~d}$ against Streptococcus iniae infection in Sunshine Bass significantly increased the final survival $\%$ to a level that was statistically indistinguishable from that of the negative control group (100\% survival). Additionally, Nile tilapia challenged with Enterococcus faecalis and fed florfenicol medicated diet $(15 \mathrm{mg} / \mathrm{kg}$ fish body weight) showed higher survivability $(83.3 \%)$ than control group $(66.7 \%)$ (Abd Ellatif et al., 2013).

\section{CONCULOSIONS}

It could be concluded that both erythromycin and florfenicol proved effective in treating bacterial infections associated with summer mortality syndrome. However, our results revealed that many important bacteria isolated from Nile tilapia farms have multiple drug resistance and this is due to the misuse of antimicrobial agents. So, we have to find another alternative way to control bacterial diseases in tilapia culture.

\section{CONFLICT OF INTEREST}

The authors declare that they don't have any conflict of interest.

\section{REFERENCES}

1. Abd El-latif, A. M., Abd El-Gawad, E. A. Abd-El-Azem, M.A 2013. Some Studies on the effect of florfenicol in Oreochromis niloticus experimentally infected with Entertococcus faecalis. The Global Journal of Fisheries \& Aqua. Research 6(6) 17-31.

2. Abdel-Latif, H.M.R., Sedeek, E.K. 2017. Diversity of enterobacteriaceae retrieved from diseased cultured Oreochromis niloticus. International Journal of Fisheries and Aquatic Studies; 5(1): 29-34.

3. Aly, S.M. A. 2013. Review of Fish Diseases in the Egyptian Aquaculture Sector: Working Report; World Fish: Penang, Malaysia, (pp. 1-41).

4. Aoki, T. 1992. Chemotheraphy and drug resistance in fish farms in Japan. In Diseases in Asian Aquaculture. Fish Health Section, Asian Fisheries Society., Edited by Shariff, M., Subasinghe, R.P., Arthur, J.P. Manila, Philippines, pp: 519-529.

5. Assefa, A., Abunna, F. Maintenance of fish health in aquaculture. 2018. Review of epidemiological approaches for 
prevention and control of infectious disease of fish. Veterinary Medicine International, 1-10.

6. Austin B, Austin D A .2007. Bacterial fish pathogens, Disease of farmed and wild fish, $4^{\text {th }}$ Ed. Springer Praxis, Godalming.

7. AVMA, 2006. Judicious use of antimicrobials for aquatic veterinarians. American Veterinary Medical Association. https://www.avma.org/KB/Policies/Pages/Judicious-Use-ofAntimicrobials-for-Treatment-of-Aquatic-Animals-byVeterinarians. aspx

8. Cabello, F.C., Godfrey, H.P., Tomova, A., Ivanova, L., Dölz, H., Millanao, A., Buschmann, A.H. 2013. Antimicrobial use in aquaculture re examined: Its relevance to antimicrobial resistance and to animal and human health. Environ. Microbiol,15, 1917-1942, doi:10.1111/1462 2920.12134.

9. Chopra, I., Roberts, M.C. 2001. Tetracycline antibiotics: mode of action, applications, molecular biology, and epidemiology of bacterial resistance. Micro biol. Mol. Biol. Rev. 65, 232 260.doi:10.1128/ MMBR.65.2.232-260.2001

10. Colom K, PèrezJ, Alonso R, Fernández-Aranguiz A, Lariňo E, Cisterna R. 2003.Simple and reliable multiplex PCR assay for detection of $b l a_{\mathrm{TEM}}, b l a_{\mathrm{SHV}}$ and $b l a_{\mathrm{OXA}-1}$ genes in Enterobacteriaceae. FEMS Microbiology Letters 223, 147-151.

11. Darwish, A. M. 2007. Laboratory efficacy of florfenicol against Streptococcus iniae infection in Sunshine Bass. J. Aquat. Anim. Health19:1-7

12. David, A., Relman, Margaret A., Hamburg., Eileen, R., Choffnes., Alison Mack. 2009. Microbial Evolution and Co Adaptation: A Tribute to the Life and Scientific Legacies of Joshua Lederberg. 0-309-13122-7, 336 pages.

13. El Gohary, F. A., Zahran, E., Abd El Gawad, E., El Gohary, A. H., Abdelhamid, F.M., El Mleeh, A., Elmahallawy, E.K.., Mona Mohieldin Elsayed, M.M.2020. Investigation of the Prevalence, Virulence Genes, and Antibiogram of Motile Aeromonads Isolated from Nile Tilapia Fish Farms in Egypt and Assessment of their Water Quality. Animals, 10, 1432.

14. Elliot, D. G. 2017. Fish viruses and bacteria: pathobiology and protection. In P. T. K. Woo, \& R. C. Cipriano (Eds.), Fish Viruses and bacteria: pathobiology and protection, 1st ed. (pp. 286- 297). Boston, Massachusetts: CABI.

15. FAO, 2017. Social and economic performance of tilapia farming in Africa.

16. Gaunt P.S., Khoo L., Leard A.T., Jack S., Santucci T., Katz T., Radecki S.V., Simmons, R. 2003. Preliminary assessment of the tolerance of and efficacy of florfenicol against Edwardsiella ictaluri administered in feed to channel catfish. Journal of Aquatic Animal Health 15, 239- 247.

17. Grape, M., Motakefi, A., Pavuluri, S. and Kahlmeter, G. 2007. Standard and real-time multiplex PCR methods for detection of trimethoprim resistance dfr genes in large collections of bacteria. European Society of Clinical Microbiology and Infectious Diseases, 13, 1112-1118.

18. Hatha, M., Vivekanandam, A.A., Joice, G.J., Christol, G.J. 2005. Antibiotic resistance pattern of motile aeromonads from farm raised freshwater fish. Int J Food Microbiol 98, 131-134.

19. Ibekwe, A.M., Murinda, S.E., Graves, A.K. (2011): Genetic Diversity and Antimicrobial Resistance of Escherichia coli from Human and Animal Sources Uncovers Multiple Resistances from Human Sources. PLoS ONE, Volume 6, Issue 6, e20819.

20. Jarau, M., MacInnes, J, I., Lumsden, J. S. 2019. Erythromycin and florfenicol treatment of rainbow trout Oncorhynchus mykiss (Walbaum) experimentally infected with Flavobacterium psychrophilum Journal of fish diseases, 42 (3) $325-334$

21. Kim, S.R., Nonaka, L., Suzuki, S. 2004. Occurrence of tetracycline resistance genes tet(M) and tet(S) in bacteria from marine aquaculture sites. FEMS Microbiol Lett 237, 147-156.

22. Manyi-Loh, C., Mamphweli, S., Meyer, E., Okoh, A. 2018 Antibiotic use in agriculture and its consequential resistance in environmental sources: potential public health implications, Molecules 23 795-843

23. Mesko, C. 1985. Fish aquaculture technology and experiments. Edited by Frederic Vogl. Pergamon Press.

24. National Committee for Clinical Laboratory Standards (NCCLS) .2000. Methods for dilution antimicrobia susceptibility tests for bacteria that grow aerobically. NCCLS, Wayne, PA. Microbiology and Microbial disease. First Published Blackwell Science Company.

25. Nguyen, M.C.P., Woerther, P., Bouvet, M., Andremont, A., Leclercq, R., Canu, A. 2009. Escherichia coli as reservoir for macrolide resistance genes. Emerging infectious diseases. 1650-1648:(10)15.

26. Noga, E.J. Fish Disease: Diagnosis and Treatment; John Wiley and Sons, Hoboken, NJ, USA, 2010

27. Okocha, R.C., Olatoye, I.O., Adedeji, O.B. 2018. Food safety impacts of antimicrobial use and their residues in aquaculture. Public Health Rev., 39:21. doi: 10.1186/s40985-018-0099-2

28. Phuoc, M.N., Bich, L.T., Giao Nguyen Trong, G.N., Chinh, Q.N. 2010. Accumulation and clearance of orally administered erythromycin in adult Nile tilapia (Oreochromis niloticus). African Journal of Food Science Vol. 4(9), pp. 591 - 596.

29. Randall, L.P., Cooles, S.W., Osborn, M.K., Piddock, L.J.V., Woodward, M.J. 2004. Antibiotic resistance genes, integrons and multiple antibiotic resistance in thirty-five serotypes of Salmonella entericaisolated from humans and animals in the UK. Journal of Antimicrobial Chemotherapy.53, 208-216.

30. Rhodes, G., Huys, G., Swings, J., McGann, P., Hiney, M., Smith, P. 2000. Distribution of oxytetracycline resistance plasmids between aeromonads in hospital and aquaculture environments: impli- cation ofTn1721indissemina- tion of the tetracycline resistance determinant TetA. Appl. Envi- ron. Microbiol. 66, 3883-3890

31. Robb, D.H.F, Crampton, V.O. 2013. On-farm feeding and feed management: perspectives from the fish feed industry. On-farm feeding and feed management in aquaculture. In: Hasan MR, New MB, eds. FAO Fisheries and Aquaculture Technical Paper No. 583. Rome: FAO. 489-518

32. Robicsek, A., Strahilevitz J., Sahm, D, F., Jacoby, G.A., Hooper, D, C. 2006. qnr prevalence in ceftazidime-resistant Enterobacteriaceae isolates from the United States. Antimicrob Agents Chemother 50:2872-2874.

33. Samuelsen, O. B., Bergh, O.2004. Efficacy of orally administered florfenicol and oxolinic acid for the treatment of vibriosis in cod (Gadus morhua). Aquaculture, 235, 27-35.

34. Samuelsen, O.B., Hjeltnes B., Glette J.1998. Efficacy of orally administered florfenicol in the treatment of furunculosis in Atlantic salmon. Journal of Aquatic Animal Health 10, 56- 61.

35. Santos, L., Ramos, F. 2018. Antimicrobial resistance in aquaculture: current knowledge and alternatives to tackle the problem. International Journal of Antimicrobial Agents, 52(2), 135-143.

Okocha, R.C., Olatoye, I.O., Adedeji, O.B. 2018. Food safety impacts of antimicrobial use and their residues in aquaculture. Public Health Rev., 39

36. Schmidt, A.S., Bruun, M.S., Dalsgaard, I., Larsen, J.L. 2001. Incidence, distribution, and spread of tetracycline resistance determinants and integron-associated antibiotic resistance genes among motile Aeromonads from a fish-farming environment. Appl Environ Microbiol 67, 5675-5682.

37. Schmidt, A.S., Bruun, M.S., Dalsgaard, I., Pedersone, K., Larsen, J.L. 2000. Occurrence of antimicrobial resistance in fish-pathogenic and environmental bacteria associated with four Danish rainbow trout farms. Appl Environ Microbiol 66 4908-4915.

38. Schwarz, S., Silley, P., Simjee, S., Woodford, N., van Duijkeren, E., Johnson., A.P., Gaastra, W. 2010. Assessing the antimicrobial susceptibility of bacteria obtained from animals. J. Antimicrob. Chemother, 4, 601-604.

39. Seljestokken B., Bergh O., Melingen G.O., Rudra H., Hetlilid Olsen R., Samuelsen O.B. 2006. Treating experimentally induced vibriosis (Listonella anguillarum) in cod, Gadus morhua L., with florfenicol. Journal of Fish Diseases 29, 737 742.

40. Soto E., Endris R.G. \& Hawke J.P. 2010. In vitro and in vivo efficacy of florfenicol for treatment of Francisella asiatica infection in tilapia. Antimicrobial Agents and Chemotherapy 54, 4664- 4670.

41. vonWintersdorff, J. Penders, J.M. vanNiekerk, N.D. Mills, S. Majumder, L.B. van Alphen. 2016. Dissemination of 
antimicrobial resistance in microbial ecosystems through horizontal gene transfer Front Microbiol, 7 (February). p. 173.

42. Watts J, E, M, Schreier H, J, Lanska L, Hale M, S. 2017. The rising tide of antimicrobial resistance in aquaculture: sources, sinks and solutions. Mar Drugs;15(158):16 pp. doi:10.3390/md15060158.

43. Youssuf, H., Abdel Gawad, E. A., El Asely, A. M., Elabd, H., Matter, A.F., Adel A. Shaheen, A.A., Abbass, A. A. 2020. Insight into summer mortalities syndrome in farmed Nile tilapia
(Oreochromis niloticus) associated with bacterial infections. BVMJ. 39:111-118.

44. Zheng, D., Frankish, A., Baertsch, R., Kapranov, P., Reymond, A., Choo, S.W., Lu, Y., Denoeud, F., Antonarakis, S.E., Snyder, M., Ruan. Y., Wei, C.L, Gingeras, T.R., Guigó, R., Harrow, J., Gerstein, M.B. 2007."Pseudogenes in the ENCODE regions: consensus annotation, analysis of transcription, and evolution". Genome Research. 17 (6): 839-51. 